\title{
Localization of heparanase in esophageal cancer cells: respective roles in prognosis and differentiation
}

\author{
Takaomi Ohkawa $^{1}$, Yoshio Naomoto ${ }^{1}$, Munenori Takaoka ${ }^{1}$, Tetsuji Nobuhisa ${ }^{1}$, \\ Kazuhiro Noma ${ }^{1}$, Takayuki Motoki ${ }^{1}$, Toshihiro Murata ${ }^{1}$, Hirokazu Uetsuka ${ }^{1}$, \\ Masahiko Kobayashi $^{1}$, Yasuhiro Shirakawa ${ }^{1}$, Tomoki Yamatsuji ${ }^{1}$, Nagahide Matsubara ${ }^{1}$, \\ Junji Matsuoka ${ }^{1}$, Minoru Haisa ${ }^{1}$, Mehmet Gunduz ${ }^{2}$, Hidetsugu Tsujigiwa ${ }^{2}$, \\ Hitoshi Nagatsuka ${ }^{2}$, Masao Hosokawa ${ }^{3}$, Motowo Nakajima ${ }^{4}$ and Noriaki Tanaka ${ }^{1}$ \\ ${ }^{1}$ Department of Gastroenterological Surgery, Transplant, and Surgical Oncology; ${ }^{2}$ Department of Oral \\ Pathology and Medicine, Graduate School of Medicine and Dentistry, Okayama University, Okayama, Japan; \\ ${ }^{3}$ Keiyukai Sapporo Hospital, Sapporo, Japan and ${ }^{4}$ Tsukuba Research Institute, Novartis Pharma KK Tsukuba, \\ Japan
}

\begin{abstract}
In this study, we examined the distribution of heparanase protein in $\mathbf{7 5}$ esophageal squamous cell carcinomas by immunohistochemistry and analyzed the relationship between heparanase expression and clinicopathological characteristics. In situ hybridization showed that the mRNA expression pattern of heparanase was similar to that of the protein, suggesting that increased expression of the heparanase protein at the invasive front was caused by an increase of heparanase mRNA in tumor cells. Heparanase expression correlated significantly with depth of tumor invasion, lymph node metastasis, tumor node metastasis (TNM) stage and lymphatic invasion. Overexpression of heparanase in esophageal cancers was also associated with poor survival. In addition to its localization in the cytoplasm and cell membrane, heparanase was also identified in the nuclei of normal epithelial and tumor cells by immunohistochemistry. Furthermore, nuclear heparanase was detected in nuclear extract of cancer cell lines by Western blot and immunohistochemistry. Examination of the role of nuclear heparanase in cell proliferation and differentiation by double immunostaining for proliferating cell nuclear antigen (PCNA) and cytokeratin 10 (CK10) showed significant relationship between nuclear heparanase expression and differentiation (heparanase vs CK10), but not for proliferative state of esophageal cancer cells (heparanase vs PCNA). Our results suggest that cytoplasmic heparanase appears to be a useful prognostic marker in patients with esophageal cancer and that nuclear heparanase protein may play a role in differentiation. Inhibition of heparanase activity may be effective in the control of esophageal tumor invasion and metastasis.
\end{abstract}

Laboratory Investigation (2004) 84, 1289-1304, advance online publication, 2 August 2004; doi:10.1038/labinvest.3700159

Keywords: differentiation; esophageal cancer; heparanase; metastasis; nuclear localization

Esophageal squamous cell carcinoma (ESCC) is one of the most aggressive malignant tumors, and its prognosis is worse than those of other gastrointestinal malignancies. The clinical outlook for patients with ESCC is still very poor, due to the high rate of local and distant metastasis. ${ }^{1-3}$ Although conventional pathological assessment has served as the standard

Correspondence: Dr Y Naomoto, MD, PhD, MBA, Department of Gastroenterological Surgery, Transplant, and Surgical Oncology, Graduate School of Medicine and Dentistry, Okayama University, 2-5-1 Shikatacho, Okayama 700-8558, Japan.

E-mail: ynaomoto@md.okayama-u.ac.jp

Received 12 March 2004; revised 27 May 2004; accepted 31 May 2004; published online 2 August 2004 estimation of prognosis of patients with esophageal carcinoma, it does not always define the individual risk of recurrence after surgical resection. Tumor cell invasion and secondary spread to blood and lymphatic vessels are the hallmarks of malignant disease and the greatest impediment to cancer therapy. Recent advances in molecular genetics of ESCC have stimulated attempts to evaluate the prognostic relevance of specific alterations in the tumor. Identification of a prognostic marker that is susceptible to or modifiable by direct therapeutic intervention should improve treatment and prognosis.

Heparanase (Hpa) is an endo- $\beta$-D-glucuronidase that specifically cleaves carbohydrate chains of heparan sulfate proteoglycans (HSPG)s. ${ }^{4}$ HSPGs are 
distributed ubiquitously and are common constituents of cell surfaces and the extracellular matrix (ECM), including basement membranes. ${ }^{5}$ HSPGs also bind and sequester a variety of bioactive proteins, including growth factors, chemokines, cytokines, and enzymes. ${ }^{6}$ After cleaving HSPGs by Hpa, HS-binding growth factors, such as bFGF, TGF$\beta$, PDGF and VEGF, are released and activated. ${ }^{7-9}$ Hpa is involved in embryonic morphogenesis, wound healing, tissue repair and inflammation. The enzyme has been identified in a variety of normal and malignant cells and tissues, for example, skin fibroblasts, cytotrophoblasts, hepatocytes, endothelial cells, platelets, mast cells, neutrophils, macrophages, T- and B lymphocytes, lymphoma, melanoma, and cancer cells. Previous studies demonstrated that the expression of Hpa gene and protein correlated with metastatic potential of several human and mouse cell lines such as breast, bladder, prostate, melanoma and T lymphoma. ${ }^{4,10-20}$ So far, Hpa has been reported to be expressed in the cytoplasm and cell surface of human carcinomas and released to outside the cell to destroy ECM and basement membranes. Stronger Hpa expression at early stages of neoplasm and in deeper cancer cells suggests that it facilitates tumor growth, invasion and metastasis. ${ }^{4,21-26}$ Hpa overexpression has been recognized in several malignant tumors and its activity in various malignant cells correlated well with their metastatic potential. ${ }^{4,27,28}$ The expression of Hpa gene and protein is reported to appear at early stages of neoplasm and gradually increases with progression from dysplasia to adenocarcinoma in colon and bladder cancers. ${ }^{22,24}$ Clinically, Hpa detection might be a useful index regarding the selection of cancer therapy because metastatic tumor-bearing animals and cancer patients show high levels of Hpa in the serum and urine. ${ }^{8}$

The present study was designed to investigate the distribution of Hpa protein and mRNA in ESCC by immunohistochemistry and in situ hybridization, and to determine the correlation between $\mathrm{Hpa}$ expression and various clinicopathological factors. Interestingly, we detected Hpa protein in the nuclei of normal epithelial and tumor cells apart from its known cytoplasmic localization by Western blotting and immunohistochemical staining. By immunostaining of proliferating cell nuclear antigen (PCNA) ${ }^{29}$ and cytokeratin 10 (CK10), ${ }^{30-32}$ markers for proliferation and differentiation, respectively, our results suggested that nuclear heparanase is involved in cell differentiation but not in cell proliferation, while cytoplasmic heparanase has a role in metastasis and prognosis.

\section{Materials and methods}

\section{Patients and Samples}

In this study, we examined 75 ESCCs, including six mucosal and 24 submucosal carcinomas obtained from previously untreated 75 patients at Keiyukai hospital, Sapporo, Japan. Patients included 69 men and six women with a mean age of 68.3 years (range, 38-79 years). The histological diagnosis of ESCC was based on the 1990 World Health Organization (WHO) International Histological Classification of Tumors. ${ }^{33}$ Invasive ESCC was classified into three types, well, moderately and poorly differentiated. Superficial ESCC represented mucosal and submucosal carcinomas, and the grade of tumor differentiation was assessed by the degree of keratinization. Two experienced pathologists, who were blinded to the clinical data and results of other diagnostic tests, assessed the histopathological diagnosis. The clinicopathological characteristics were evaluated according to guidelines of the Union Internationale Contre le Cancer (UICC). The study protocol was approved by the Human Ethics Review Committees of the participating universities.

\section{Cell Lines and Cultures}

Human esophageal squamous cell cancer cell lines, TE1, TE6 and TE8 from the Japanese Cancer Research Resources Bank (Tokyo), and T.Tn from the Japan Cell Research Bank (Ibaraki, Japan), were obtained. The cell lines were propagated in monolayer cultures in RPMI 1640 with $25 \mathrm{mM}$ HEPES, $10 \%$ FCS, $100 \mathrm{U} / \mathrm{ml}$ penicillin and $100 \mathrm{mg} / \mathrm{ml}$ streptomycin at $37^{\circ} \mathrm{C}$ in a humidified atmosphere of $95 \%$ air $-5 \% \mathrm{CO}_{2}$. TE1 and TE6 were derived from well-differentiated squamous cell carcinoma, whereas TE8 and T.Tn originated from moderately and poorly differentiated squamous cell carcinomas, respectively. Primary esophageal keratinocytes, designated as KOB, from normal human esophagus were established as described previously. ${ }^{34}$ Briefly, surgical specimens from normal esophagi were promptly removed and aseptically transferred into Hank's solution (Life Technologies, Grand Island, $\mathrm{NY}$, USA) with $100 \mathrm{U} / \mathrm{ml}$ penicillin, $100 \mu \mathrm{g} / \mathrm{ml}$ streptomycin (Life Technologies) and $5 \mu \mathrm{g} / \mathrm{ml}$ gentamycin (Life Technologies). The tissue specimen was incubated with $1.5 \mathrm{U} / \mathrm{ml}$ dispase (Roche Molecular Biochemicals, Indianapolis, IN, USA) at $4^{\circ} \mathrm{C}$ overnight and the epithelium was dissected away and incubated with trypsin (Life Technologies). The reaction was stopped with soybean trypsin inhibitor (Sigma, St Louis, MO, USA) and centrifuged. The pellet was resuspended in Keratinocyte-SFM medium (KSFM) (Life Technologies) supplemented with $40 \mu \mathrm{g} / \mathrm{ml}$ bovine pituitary extract (BPE) (Life Technologies), $1.0 \mathrm{ng} / \mathrm{ml}$ EGF (Life Technologies), $100 \mathrm{U} / \mathrm{ml}$ penicillin, $100 \mu \mathrm{g} / \mathrm{ml}$ streptomycin (Life Technologies), $5 \mu \mathrm{g} / \mathrm{ml}$ gentamycin and $100 \mathrm{U} / \mathrm{ml}$ nystatin (Life Technologies). KOB cells were grown at $37^{\circ} \mathrm{C}$ and $5 \% \mathrm{CO}_{2}$ with $\mathrm{KSFM}$, with $40 \mu \mathrm{g} / \mathrm{ml}$ $\mathrm{BPE}, 1.0 \mathrm{ng} / \mathrm{ml} \mathrm{EGF}$, and $100 \mathrm{U} / \mathrm{ml}$ penicillin, and $100 \mu \mathrm{g} / \mathrm{ml}$ streptomycin. 


\section{Monoclonal Antibodies}

Anti-human mouse heparanase monoclonal antibody was obtained from Novartis Pharma (Tsukuba, Japan). The monoclonal antibody reacted with both $65 \mathrm{kDa}$ proform and $50 \mathrm{kDa}$ mature form of the human Hpa, as described previously. ${ }^{35}$ Clones PC10 for PCNA and DE-K10 for CK10 were obtained from Dako (Dako Japan Co., Tokyo, Japan). Clone SY5 for involucrin was obtained from Sigma (SigmaAldrich Inc., St Louis, USA). Antibody for human Hpa was diluted at 1:500. Clone SY5 was diluted at 1:100. Clones PC10 and DE-K10 were ready to use.

\section{Tissue and Probe Preparation for In Situ Hybridization}

The specimens were immersed in $4 \%$ paraformaldehyde solution in phosphate buffer. All fixed specimens were embedded in paraffin, and $4-\mu \mathrm{m}$ sections were prepared. Digoxigenin-11-UTP-labeled single-strand RNA probes were prepared using a DIG Labeling Kit (Roche Diagnostics GmbH, Penzberg, Germany) according to the manufacturer's instructions. For generation of the heparanase probe, a 571-bp fragment of human heparanase cDNA (bases 261-832 of the total cDNA (Gene Bank Accession No. AF144325)) was obtained by RT-PCR and was subcloned into pCR21 (Invitrogen).

\section{In Situ Hybridization Procedure}

We performed in situ hybridization as described previously. ${ }^{35}$ Briefly, the sections were deparaffinized, rehydrated, and incubated with $3 \mathrm{mg} / \mathrm{ml}$ of proteinase K (Roche Diagnostics) in $10 \mathrm{mM}$ Tris-HCl (pH 8.0) and $1 \mathrm{mM}$ EDTA for $10 \mathrm{~min}$ at $37^{\circ} \mathrm{C}$. Acetylation of the sections was performed by incubating with freshly prepared $0.25 \%$ acetic anhydride in $0.1 \mathrm{M}$ triethanolamine- $\mathrm{HCl}$ buffer $(\mathrm{pH}$ 8.0) for $10 \mathrm{~min}$ at room temperature. The hybridization solution contained $50 \%$ deionized formamide, $10 \%$ dextran sulfate, $1 \times$ Dehardt's solution, $600 \mathrm{mM}$ $\mathrm{NaCl}, 0.25 \%$ SDS, $250 \mathrm{mg} / \mathrm{ml}$ of Escherichia coli tRNA (proteinase treated) $10 \mathrm{mM}$ dithiothreitol, and $0.1-2.0 \mathrm{mg} / \mathrm{ml}$ of digoxigenin-UTP-labeled RNA probe. The probe was placed on the sections and covered by parafilm and incubated at $50^{\circ} \mathrm{C}$ for $16 \mathrm{~h}$ in a moisture chamber. After hybridization, the slides were incubated with $50 \%$ formamide in $2 \times$ SSC for $30 \mathrm{~min}$ at $50^{\circ} \mathrm{C}$ to remove the excess probe. The slides were incubated with $2 \times$ SSC and $0.2 \times$ SSC for $15 \mathrm{~min}$ twice at $50^{\circ} \mathrm{C}$. The washed slides were incubated with DIG buffer $1(100 \mathrm{mM}$ Tris-HCl, $\mathrm{pH} 7.5,150 \mathrm{mM} \mathrm{NaCl}$ ) for $60 \mathrm{~min}$ at room temperature. A $100 \mu \mathrm{l} / \mathrm{cm}^{2}$ specimen of diluted polyclonal sheep anti-digoxigenin Fab fragment (1:1000) in DIG buffer 1 was mounted on the sections and incubated for $30 \mathrm{~min}$ at room temperature. Coloring solution containing $337.5 \mu \mathrm{g} / \mathrm{ml}$ of nitroblue tetrazolium and $165 \mu \mathrm{g} / \mathrm{ml}$ of 5 -bromo-4chloro-3-indolyl phosphate in DIG buffer $3(100 \mathrm{mM}$ Tris-HCl, $\mathrm{pH}$ 9.5, $100 \mathrm{mM} \mathrm{NaCl}, 50 \mathrm{mM} \mathrm{MgCl}_{2}$ ) was mounted on the sections and incubated at room temperature or $37^{\circ} \mathrm{C}$ until the signal-noise ratio was maximum. The slides were mounted with counterstaining by methyl green. The controls included (a) hybridization with the sense (mRNA) probe, (b) RNAase treatment $(20 \mathrm{mg} / \mathrm{ml})$ hybridization, and (c) the use of neither antisense nor antidigoxigenin antibody. None of the controls showed positive signals.

\section{Immunohistochemistry}

Staining for Hpa, CK10 and PCNA was performed using formalin-fixed, paraffin-embedded serial sections. Sections $(5-\mu \mathrm{m}$ thick) were mounted on silanized slides (Dako), deparaffinized in xylene for $20 \mathrm{~min}$ and rehydrated in graded ethanol solutions. Endogenous peroxidase was blocked by incubating the sections in $3.0 \% \mathrm{H}_{2} \mathrm{O}_{2}$ in methanol for $15 \mathrm{~min}$. For Hpa staining, antigen retrieval on paraffin sections was performed by heating in $10 \mathrm{mM}$ citrate buffer solution ( $\mathrm{pH}$ 6.0) in a microwave for $5 \mathrm{~min}$. After blocking of nonspecific reactivity with rabbit serum for $10 \mathrm{~min}$ at room temperature (Histofine SAB PO kit; Nichirei, Tokyo, Japan), sections were incubated overnight at $4^{\circ} \mathrm{C}$ with the anti-heparanase and anti-PCNA antibodies, or for $1 \mathrm{~h}$ at $37^{\circ} \mathrm{C}$ with anti-CK10 antibody. The distribution of the primary antibody was achieved by subsequent application of a biotinylated antiprimary antibody (Histofine SAB PO kit) and streptavidin-peroxidase (Histofine $\mathrm{SAB}$ PO kit). Immunostaining was developed using $\mathrm{DAB} / \mathrm{H}_{2} \mathrm{O}_{2}$ solution (Histofine DAB substrate kit; Nichirei), and sections were counterstained with Mayer's hematoxylin. As a negative control, some sections were subjected to normal serum blocking and omission of the primary antibody. In each lesion, assessment of Hpa was based on the nuclear or cytoplasmic staining patterns. Assessment of $\mathrm{PCNA}^{29}$ was based on the nuclear staining patterns, and assessments of CK $10^{30-32}$ were based on the cytoplasmic staining patterns. ${ }^{32}$ Immunostaining signals at the invasive front were scored by two independent examiners without knowledge of the clinicopathological features of the patients. Each microscopic examination included two random sections from the invasive front. The scores were calculated as the total number of stained cells divided by total number of carcinoma cells. Cases were considered positive for Hpa immunostaining when more than $10 \%$ of cancer cells at the invasive front and tumor edge showed cytoplasmic staining only or both cytoplasmic and nuclear staining. CK10 immunopositivity was assessed as described previously. ${ }^{32}$ PCNA expression was considered positive if nuclei of tumor cells were stained stronger than normal cells. 


\section{Double Staining for Heparanase and PCNA}

At first, heparanase staining was performed and endogenous peroxidase was not blocked. Antigen retrieval on paraffin sections was performed by heating in $10 \mathrm{mM}$ citrate buffer solution ( $\mathrm{pH}$ 6.0) in a microwave for $5 \mathrm{~min}$. Subsequent application of biotinylated anti-primary antibody (Histofine SABAP kit) and alkaline phosphatase (Histofine SAB-AP kit) allowed identification of the distribution of the primary antibody. Immunostaining was developed using First Blue solution (Histofine First Blue substrate kit; Nichirei). Then, in the sections in which heparanase immunostaining was performed, antigen retrieval was performed once by heating in $10 \mathrm{mM}$ citrate buffer solution ( $\mathrm{pH}$ 6.0) in a microwave for $5 \mathrm{~min}$. PCNA staining was performed by using Hrp-conjugated PCNA antibody (Dako). Subsequent application of a biotinylated antiprimary antibody (Histofine SAB-PO kit) and streptavidin-peroxidase (Histofine SAB-PO kit) allowed identification of the distribution of the primary antibody. Immunostaining was developed using AEC solution (Histofine AEC substrate kit; Nichirei). Double staining of Hpa and PCNA was performed in 12 well-differentiated ESCC cases and the percentage of immunoreactive cells was evaluated semiquantitatively by counting at least 500 cells in the most representative area. Only N-Hpa positive, only PCNA positive, N-Hpa/PCNApositive and N-Hpa/PCNA-negative-stained cells were counted among cancer cells.

\section{Western Blot Analysis}

Cells were collected by trypsinization and washed twice in cold PBS. Whole cell protein was collected as follows. Cells then were dissolved in lysis buffer containing $50 \mathrm{mM}$ Tris-HCl (pH 7.5), $150 \mathrm{mM} \mathrm{NaCl}$, $0.5 \%$ Triton $\mathrm{X}-100$, and protease inhibitors $(0.2 \mathrm{mM}$ phenylmethylsulfonyl fluoride, $0.2 \mathrm{mM}$ 4-(2-aminoethyl) benzenesulfonylfluoride, $\mu \mathrm{g} / \mathrm{ml}$ leupeptin, $10 \mu \mathrm{g} / \mathrm{ml}$ pepstatin, and $1 \mu \mathrm{g} / \mathrm{ml}$ aprotinin). The lysis was carried out at $4{ }^{\circ} \mathrm{C}$ for $30 \mathrm{~min}$ and centrifuged at $15000 \mathrm{rpm}$. Nuclear extract of esophageal cancer cells were collected using NER-PER ${ }^{\mathrm{TM}}$ extract reagent (PIERCE, Rockford, IL, USA). The protein concentration of the supernatant was determined using the Bio-Rad protein determination method (Bio-Rad, Hercules, CA, USA). Equal amounts $(60 \mu \mathrm{g})$ of proteins were electrophoresed under reducing conditions on $12 \%(\mathrm{w} / \mathrm{v})$ polyacrylamide gels. Proteins were electrophoretically transferred to a Hybond-polyvinylidene difluoride transfer membranes (Amersham, Arlington Heights, IL, USA) and incubated with primary antibodies against heparanase, $\beta$-actin and Transcription factor IIH (TFIIH) (as a control for nuclear protein), then peroxidaselinked secondary antibody. An Amersham enhanced chemiluminescence chemiluminescent Western system (Amersham, Tokyo, Japan) was used to detect secondary probes.

\section{Analysis of Relationship between Heparanase Expression and Clinicopathological Factors}

Hpa immunostaining was detected both in the cytoplasm and nucleus. Therefore, cases were divided into two groups based on Hpa immunostaining as cytoplasmic (C-Hpa) or nuclear heparanase (N-Hpa). We compared the two groups and analyzed the interaction between Hpa expression and clinicopathological characteristics, and evaluated it as a prognostic factor for esophageal cancer patients.

\section{Statistical Analysis}

Two-tailed $\chi^{2}$-test was used for assessment of the relationship between Hpa expression and clinicopathological parameters. Overall survival was calculated using the Kaplan-Meier method and compared by the Wilcoxon test. Differences in CK10 expression between N-hpa positive and negative groups were examined using the unpaired $t$-test. Differences in the percentages of doublestained cells with Hpa and PCNA were assessed by using $\chi^{2}$ two-tailed test. Data are expressed as mean \pm s.d. A $P$-value less than 0.05 denoted the presence of a statistically significant difference.

\section{Results}

\section{Distribution of Heparanase Protein in Normal and Cancerous Esophageal Tissues}

The nuclei and not cytoplasm of epithelial cells and intercellular bridges in parabasal layers were stained for Hpa in most normal esophageal epithelial tissues. Endothelial and epithelial cells of papilla showed moderate expression. In the stroma adjacent to tumor tissues, vascular endothelial cells and fibroblasts were weakly stained for Hpa. Inflammatory cells, such as macrophages and lymphocytes showed strong expression (Figure 1a-c).

\footnotetext{
Figure 1 Immunohistochemical analysis of the heparanase protein in normal esophageal epithelium (a,b), dysplasia (d-f) and carcinoma in situ (g-i). (a) Epithelial cells immunostained for heparanase. Note the lack of heparanase expression in the cytoplasm of epithelial cells, while the nuclei of squamous epithelium in the parabasal and middle layers are stained (arrows). (b) Staining of intercellular bridge and endothelial cells of papilla (arrows). (c) Staining of vascular endothelial cells (arrows) and inflammatory cells (pointed arrows) (d-f) Moderate level of Hpa expression is detected in dysplastic lesions. Moderate dysplasia (e) and severe dysplasia (f) show stronger Hpa expression than mild dysplasia (d). (g-i) In situ esophageal cancers show mild expression of heparanase. (g) Diffuse staining of heparanase in a replacing type tumor. Strong staining of heparanase at invasive front of basal (h) and bulky downgrowth type tumors (i). Original magnifications, $\times 100(\mathbf{a}), \times 400(\mathbf{b}, \mathbf{c}), \times 200(\mathbf{d}-\mathbf{h})$, and $\times 150(\mathbf{i})$.
} 



\section{g}

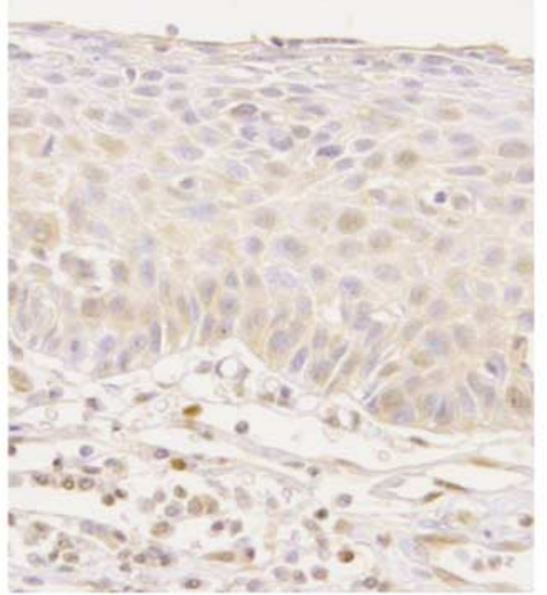

h

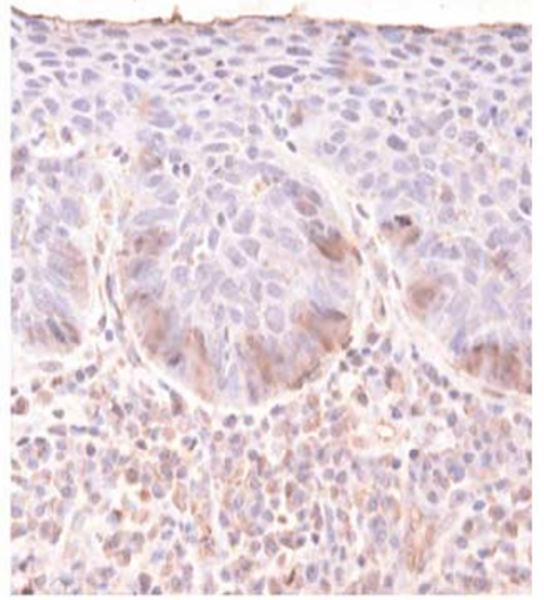

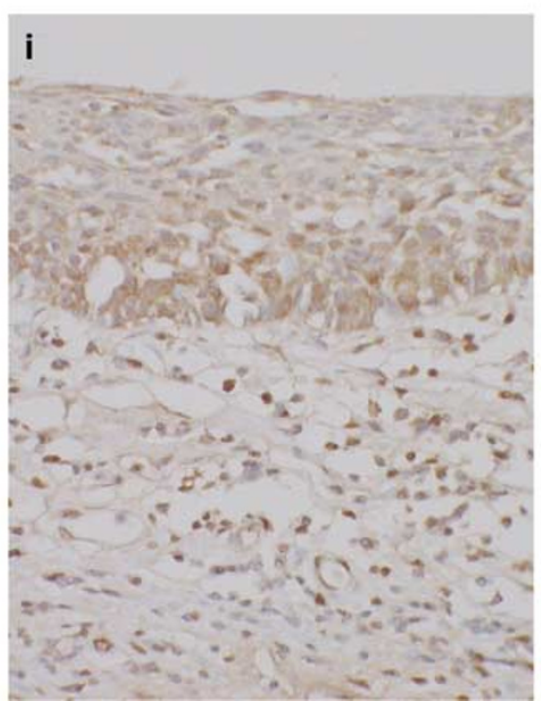


Staining for Hpa in the stromal tissues adjacent to the tumor tissues was stronger than in normal stromal tissue (data not shown). Fair Hpa expression was observed in dysplastic areas. Severe and moderate dysplasia showed stronger expression than mild dysplasia (Figure 1d-f). Three types of esophageal carcinoma in situ were observed: basal, bulky downgrowth, and replacing. In the first two types, Hpa was expressed in the cytoplasm of cancer cells at the invasive front. However, weak Hpa expression was detected in the cytoplasm and nuclei of replacing type cancer cells (Figure 1g-i).

With regards to invasive tumors, we found four staining patterns, (1) Hpa expressed only in the cytoplasm, (2) Hpa expressed only in the nucleus,
(3) Hpa expressed both in the cytoplasm and nucleus, (4) Negative Hpa expression both in the cytoplasm and nucleus (Figure 2). Well and moderately differentiated ESCCs (Figure 3a-d) showed Hpa expression in the cytoplasm and nucleus of cancer cells at the tumor edge and invasive front, whereas in poorly differentiated ESCCs, Hpa was expressed only in the cytoplasm of most tumor cells (Figure 3e and f). We also examined the metastatic lymph nodes from six primary ESCCs. Hpa was less or equally expressed in comparison with the corresponding primary lesions. The nuclei of metastatic cancer cells also showed Hpa expression (Figure $3 \mathrm{~g}$ and $\mathrm{h}$ ). Vascular endothelial cells in tumoral stroma nests showed strong heparanase expression (Figure 3i).
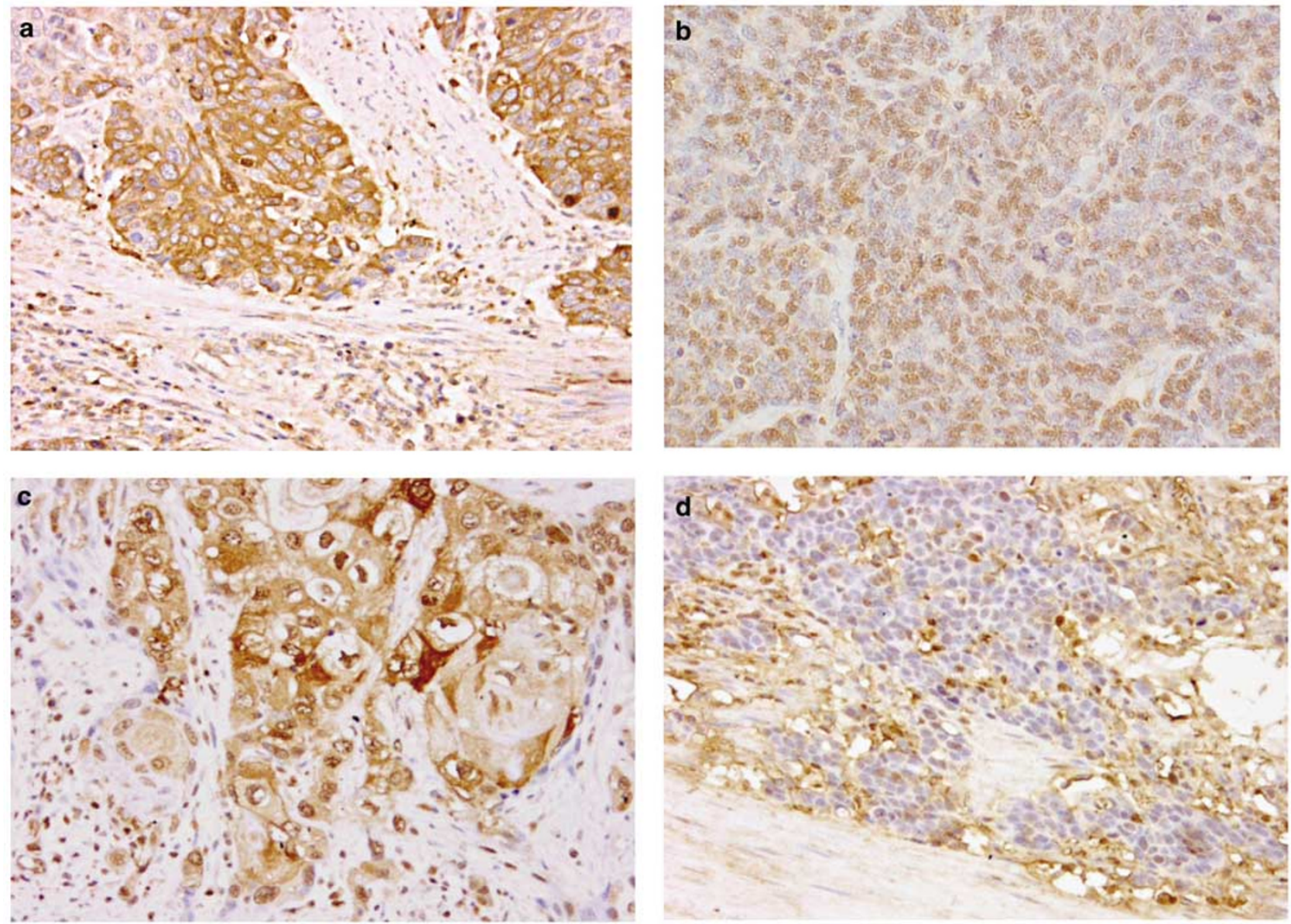

Figure 2 Intracellular heparanase staining patterns in tumor cells (a-d). Positive staining for heparanase in the cytoplasm only (a), in nucleus only (b) or in both the cytoplasm and nucleus (c). Note the negative heparanase staining in both the cytoplasm and nucleus (d). Heparanase staining in the cytoplasm only or in both the cytoplasm and nucleus was considered as positive immunoreaction in the present study $(\mathbf{a}, \mathbf{c})$ Original magnifications, $\times 400$.

Figure 3 Heparanase immunostaining in primary invasive tumor tissue (a-f and $\mathbf{h}$ ) and metastatic lesion (g). Positive immunostaining especially at tumor edge and invasive front in well-differentiated squamous carcinoma (a,b), moderately differentiated squamous carcinoma (c, d), and poorly differentiated squamous carcinoma $(\mathbf{e}, \mathbf{f})$. Well and moderately differentiated squamous carcinoma cells $(\mathbf{a}-$ d) also showed strong heparanase expression in the nucleus, whereas poorly differentiated tumors (e,f) show no heparanase expression in the nucleus. Metastatic esophageal cancer in a regional lymph node (g) exhibits less or equal heparanase expression relative to its expression in the primary lesion (h). Vascular endothelial cells in tumoral stroma have strong heparanase expression (i) (arrows). Original magnifications: $\times 100(\mathbf{a}), \times 150(\mathbf{c}), \times 200(\mathbf{b}-\mathbf{h})$, and $\times 300(\mathbf{i})$. 


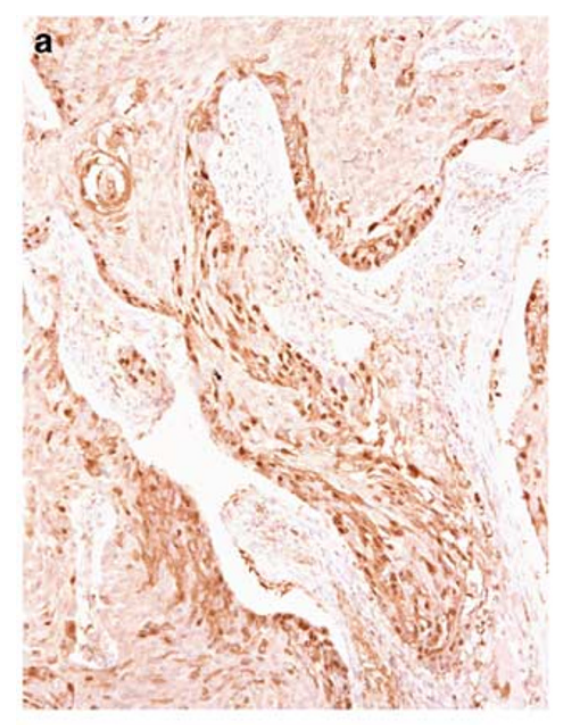

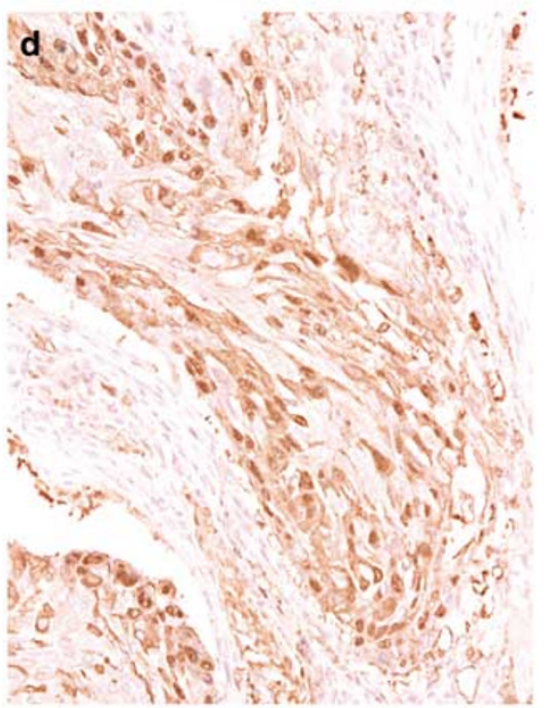

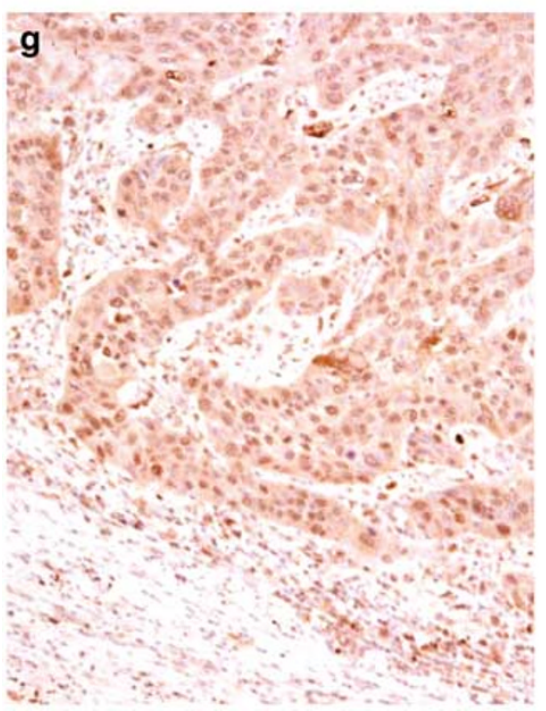

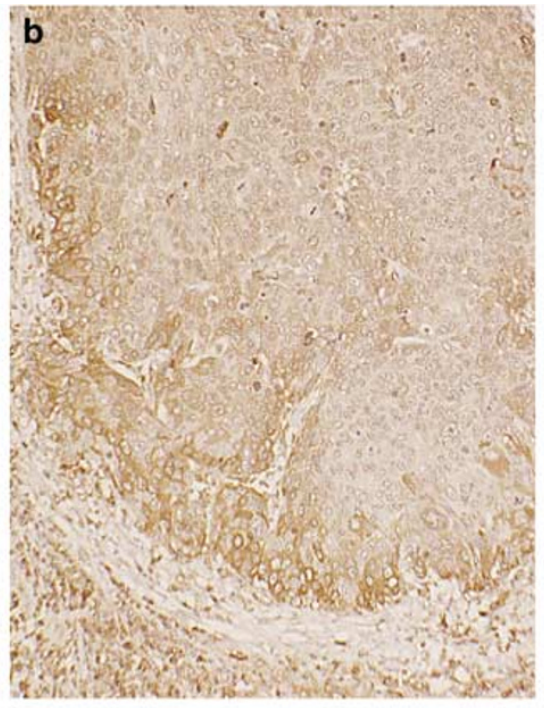
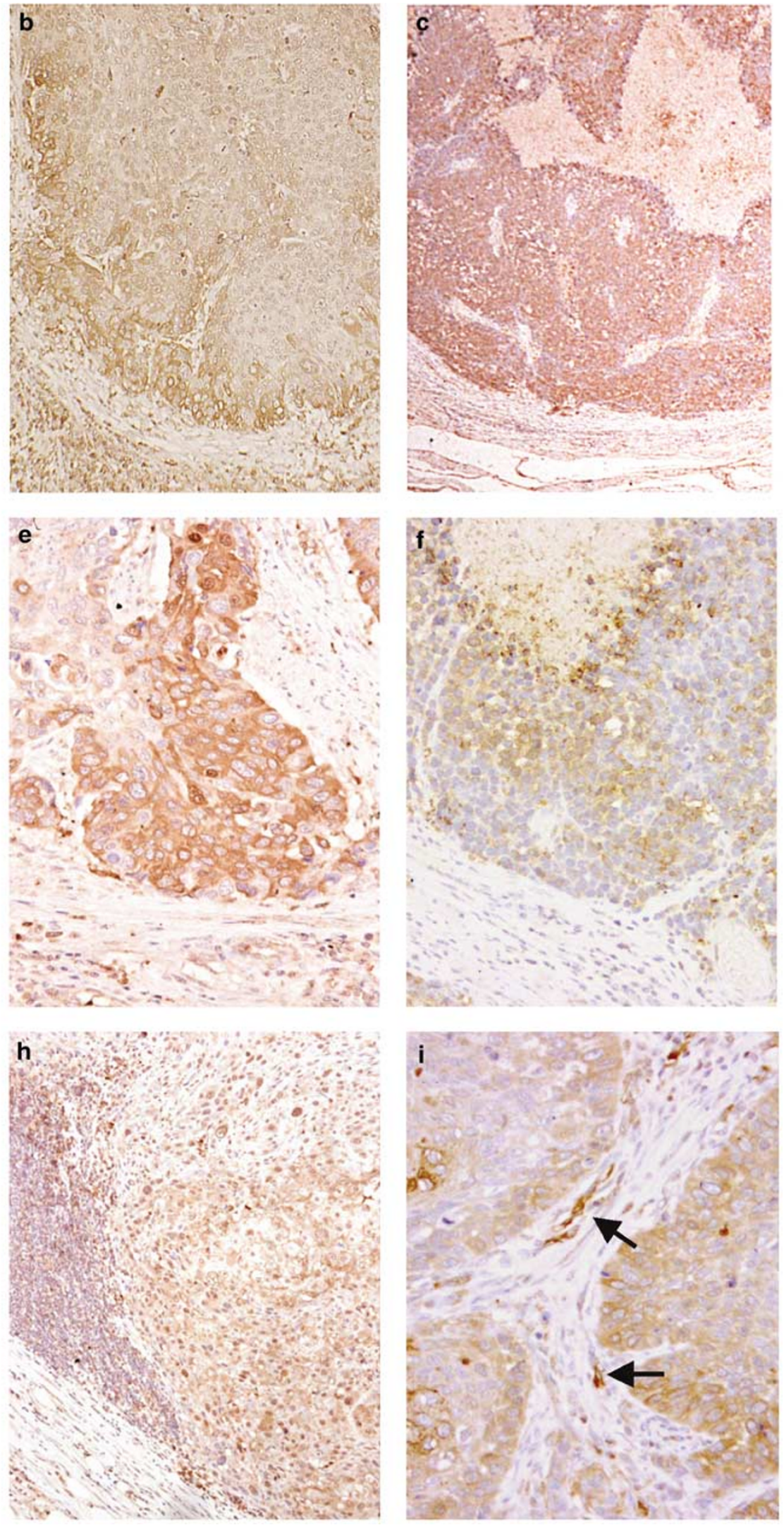


\section{Expression Pattern of the Heparanase mRNA}

Hpa could originate in platelets and fibroblasts and be deposited at sites of tissue injury. To investigate the origin of Hpa and the correlation between the localization of Hpa protein and mRNA, in situ hybridization from eight representative samples of esophageal cancer was performed. As shown in Figure 4, the mRNA expression pattern of Hpa was similar to that of the protein. No positive labeling of Hpa mRNA was identified in normal mucosal epithelium (Figure 4a). Dysplastic lesion showed fairly Hpa expression (Figure 4b). Figure 4c showed Hpa mRNA expression at the junctional lesion between normal esophageal epithelium and carcinoma in situ. Tumor tissues showed positive labeling of Hpa mRNA (Figure $4 \mathrm{~d}-\mathrm{f}$ ). In particular, tumor cells strong labeling at the invasive front (Figure 4e and f). Moreover, fibroblasts, inflammatory cells and vascular endothelium in stromal tissue near the tumor mass also showed positive Hpa labeling (Figure 4g and $\mathrm{h}$ ).

\section{Relationship between Heparanase Expression and Clinicopathological Factors}

Frequent lymph node metastasis occurs in most esophageal carcinomas with invasion into the submucosal tissues. Hpa expression in the cytoplasm and nuclei of carcinoma cells was stronger in larger tumors than in small tumors. However, Hpa was not expressed in the keratinized tumor tissues. Our results showed that 51 of 75 (68\%) ESCC cases were stained positively for C-Hpa (Table 1). C-Hpa expression significantly correlated with the depth of invasion $(P=0.0028)$. None of Tis cases were CHpa positive $(0 \%)$. While the percentage of C-Hpapositive cases increased in a stepwise fashion from T1a to T4, and in T4 lesions, most cases was C-Hpa positive. Out of $38,30(78.9 \%)$ tumors with lymph node metastasis showed positive C-Hpa expression, while C-Hpa was stained in 21 out of 37 (56.8\%) of tumors without lymph node involvement $(P=0.0394)$. C-Hpa staining gradually increased from stage 1 through $4(P=0.0154)$. At stage 4 , seven of 10 cases $(70 \%)$ demonstrated positive staining, while only one of five $(20 \%)$ tumors was stained for C-Hpa at stage 1. Out of 35, $30(85.7 \%)$ tumors with lymphatic invasion displayed C-Hpa expression, while 21 out of $40(50.3 \%)$ tumors without lymphatic invasion showed C-Hpa staining $(P=0.0028)$. On the other hand, in regard to N-Hpa, its expression was significantly correlated with differentiation, depth of invasion and tumor node mteastasis (TNM) stage (Table 1).

We also examined the survival of 75 ESCCs in Hpa-positive and -negative cases. The survival rate at 5-year after surgery was $75 \%$ in patients with negative C-Hpa expression, while it was significantly lower $(33.3 \%)$ in patients with positive C-Hpa immunoreactivity $(P<0.001)$ (Figure 5a).
However, there was no significant difference in survival rate between positive and negative staining for N-Hpa, suggesting that N-Hpa is not an independent prognostic factor (Figure $5 b$ ).

\section{Detection of Heparanase in Nuclei of Esophageal Cancer Cell Lines and Normal Esophageal Keratinocyte}

Firstly, we performed immunohistochemical staining of esophageal squamous cancer cell lines and normal esophageal keratinocytes (KOB cells). Normal esophageal epithelial cells change their size and shape when they differentiate into keratinocyte. In immunohistochemistry, involucrin, a differentiation marker of squamous cells, was expressed in keratinized KOB cells with large size and flat shape (Figure 6c). Keratinized KOB cells have Hpa expression only in cytoplasm. However, Hpa was expressed in both nucleus and cytoplasm of nonkeratinized KOB cells (Figure 6a and b). In addition, two well-differentiated cancer cell lines, TE1 and TE6, showed similar staining patterns with KOB cells (Figure 7a-d). On the other hand, TE8, a moderately differentiated squamous cancer cell line, and T.Tn, a poorly differentiated squamous cancer cell line, expressed small amounts of nuclear heparanase (Figure 7e-h). Furthermore, we extracted nuclear protein from these esophageal cancer cell lines and performed Western blotting. Figure 8 showed that all cell lines have heparanase protein in nuclear extract.

\section{Double Staining of Heparanase and PCNA}

The lack of correlation between nuclear expression of Hpa and prognosis suggested that N-Hpa could play some important roles other than cell to ECM interaction. Examination of PCNA and Hpa expressions by immunohistochemistry showed that both of them were expressed at the tumor edge, and the staining patterns were very similar (data not shown). Furthermore, we performed double staining by using anti-Hpa and anti-PCNA antibodies. However, there was no significant relationship between N-Hpa and PCNA expression, suggesting that N-Hpa was not involved in cell proliferation (data not shown).

\section{Positive Relationship between Expression of Nuclear Heparanase and CK10}

In the next step, we examined CK10 expression by immunohistochemical staining as described previously. ${ }^{32}$ CK10 was expressed in the cytoplasm of differentiated squamous cancer cells (Figure 9). Table 2 shows the relationship between N-Hpa and CK10. CK10 was expressed in 48 of 75 (64\%) cancer cases, and was detected in 31 of $37(83.4 \%)$ well differentiated, 17 of 31 (54.8\%) moderately differ- 
a

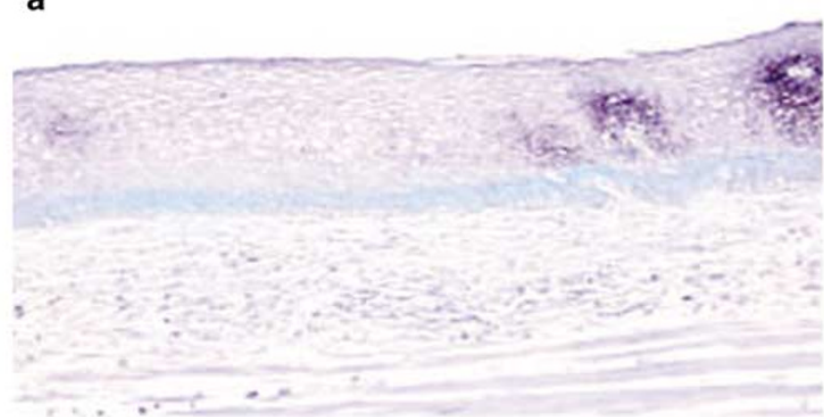

C
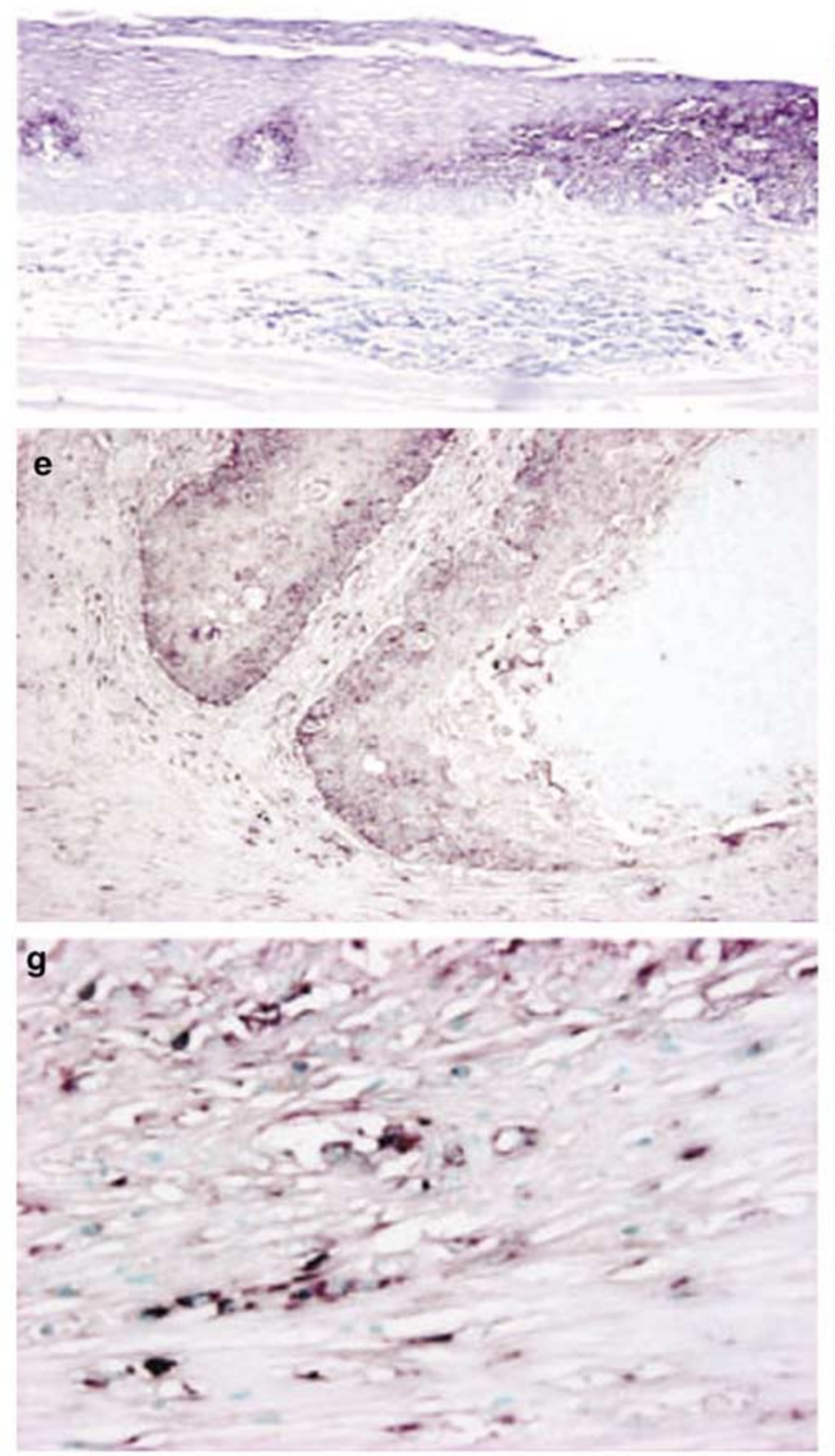

b
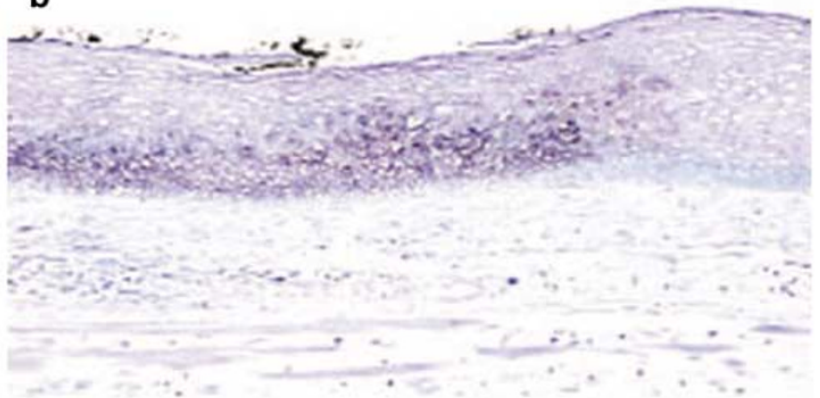

d
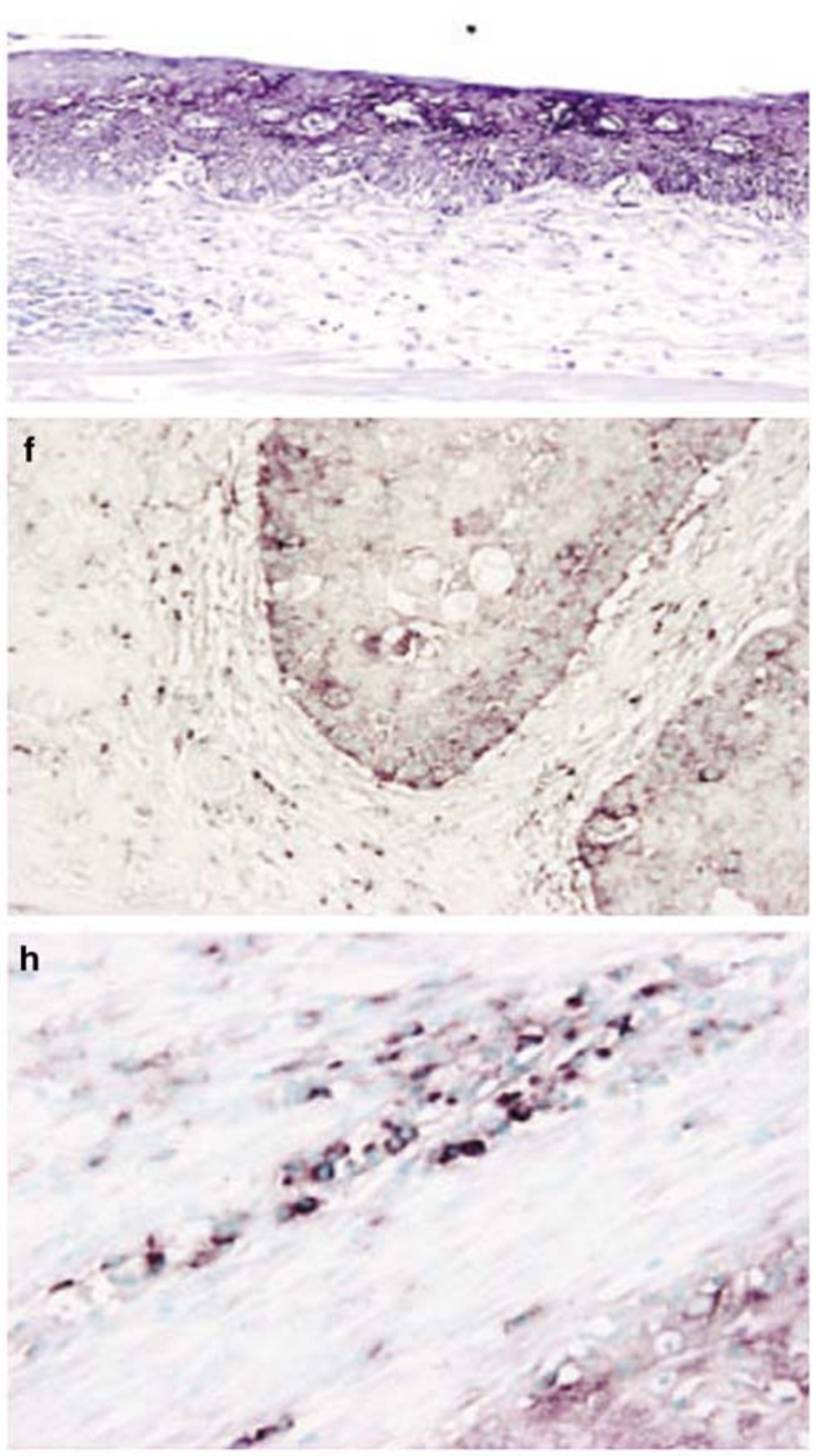

Figure 4 Heparanase mRNA (in situ hybridization) in ESCC. Positive labeling (signal) is purple. (a) Normal esophageal epithelium did not have heparanase gene expression $(\times 200)$. (b) Dysplasia of esophagus has weak heparanase mRNA expression. $(\times 200)$. (c) Junctional lesion between normal esophageal epithelium and carcinoma in situ $(\times 200)$. (d) Carcinoma in situ showed strong heparanase gene expression (in the all layers) $(\times 200)$. (e) Tumor cells showed strong expression of the heparanase mRNA $(\times 200)$. (f) Tumor cells at the invasive front demonstrated strong expression of the heparanase mRNA $(\times 200)$. $(\mathbf{g}, \mathbf{h})$ Stromal cells such as fibroblasts, inflammatory cells and vascular endothelium near tumor tissue also showed positive Hpa labeling $(\times 600)$. 
Table 1 Relationship between heparanase expression and clinicopathological parameters in esophageal squamous cell carcinoma

\begin{tabular}{|c|c|c|c|c|c|c|}
\hline \multirow[t]{2}{*}{ Category } & \multicolumn{2}{|c|}{ C-Heparanase } & & \multicolumn{2}{|c|}{$N$-Heparanase } & \\
\hline & Negative & Positive & & Negative & Positive & \\
\hline \multicolumn{7}{|c|}{ Differentiation } \\
\hline Well & 9 & 29 & \multirow{4}{*}{ N.S } & 12 & 26 & \multirow{4}{*}{0.0277} \\
\hline Mod & 12 & 18 & & 16 & 14 & \\
\hline Poor & 1 & 4 & & 4 & 1 & \\
\hline Unknown & 2 & 0 & & 2 & 0 & \\
\hline \multicolumn{7}{|l|}{ Depth (T) } \\
\hline Tis & 3 & 0 & \multirow{6}{*}{0.0028} & 3 & 0 & \multirow{6}{*}{0.0292} \\
\hline T1a & 2 & 1 & & 2 & 1 & \\
\hline $\mathrm{T} 1 \mathrm{~b}$ & 12 & 12 & & 14 & 12 & \\
\hline $\mathrm{T} 2$ & 1 & 10 & & 2 & 10 & \\
\hline T3 & 6 & 24 & & 13 & 13 & \\
\hline $\mathrm{T} 4$ & 0 & 4 & & 0 & 5 & \\
\hline \multicolumn{7}{|c|}{ Lymph node metastasis (N) } \\
\hline No & 16 & 21 & \multirow{2}{*}{0.0394} & 19 & 17 & \multirow[t]{2}{*}{ N.S. } \\
\hline N1 & 8 & 30 & & 15 & 24 & \\
\hline \multicolumn{7}{|c|}{ Distant metastasis (M) } \\
\hline Mo & 21 & 44 & \multirow{3}{*}{ N.S. } & 27 & 38 & \multirow{3}{*}{ N.S. } \\
\hline M1a & 3 & 5 & & 6 & 2 & \\
\hline M1b & 0 & 2 & & 1 & 1 & \\
\hline \multicolumn{7}{|l|}{ TNM stage } \\
\hline 0 & 4 & 1 & \multirow{5}{*}{0.0154} & 4 & 1 & \multirow{5}{*}{0.003} \\
\hline 1 & 8 & 7 & & 11 & 4 & \\
\hline 2 & 7 & 21 & & 8 & 20 & \\
\hline 3 & 2 & 15 & & 4 & 13 & \\
\hline 4 & 3 & 7 & & 7 & 3 & \\
\hline \multicolumn{7}{|c|}{ Lymphatic invasion } \\
\hline $\operatorname{ly}(-)^{\mathrm{a}}$ & 19 & 21 & \multirow[t]{2}{*}{0.0028} & 22 & 18 & \multirow[t]{2}{*}{ N.S. } \\
\hline $\operatorname{ly}(+)$ & 5 & 30 & & 12 & 23 & \\
\hline \multicolumn{7}{|c|}{ Vessel invasion } \\
\hline $\mathrm{v}(-)^{\mathrm{a}}$ & 24 & 45 & \multirow[t]{2}{*}{0.0798} & 31 & 38 & \multirow[t]{2}{*}{ N.S. } \\
\hline $\mathrm{v}(+)$ & 0 & 6 & & 3 & 3 & \\
\hline
\end{tabular}

${ }^{\mathrm{a}}(-)$ and $(+)$ indicate absence and presence of lymphatic and vessel invasion, respectively.

N.S., not significant.

entiated, zero of five $(0 \%)$ poorly differentiated SCC. $\mathrm{N}-\mathrm{H} p a$ was positive in 32 out of $48(66.7 \%)$ CK10positive cases, while nine out of $27(33.3 \%)$ tumors negative for CK10 showed immunoreactivity with N-Hpa $(P=0.0078)$ (Table 2). In contrast, C-Hpa expression did not correlate with CK10 expression and differentiation (data not shown).

\section{Discussion}

In this study, we examined Hpa expression in ESCCs and its relationship with clinicopathological factors, proliferation and differentiation. With regard to ECM degrading enzymes, such as metallo-proteinases ${ }^{36}$ the interaction between these enzymes and stromal tissues is very important for tumor progression and metastasis. ${ }^{19,37,38}$ Therefore, strong Hpa expression was detected in cells of the stroma adjacent to tumor tissues including epithelial cells, vascular endothelial cells, fibroblasts and inflammatory cells such as macrophages, lymphocytes and neutrophils. Immunohistochemical staining of Hpa in vascular sprouts in tumors was also described previously. ${ }^{22,39}$ Marchetti et $a l^{40}$ reported that coincubation of astrocytes with brain-metastatic melanoma cells resulted in a superadditive effect on Hpa activity, which in turn contributed to the brain colonization of melanoma cells through layers of blood-brain barrier.

In our study, various clinicopathological parameters, such as depth of invasion (pT), nodal metastasis (pN), TNM stage and lymphatic invasion, correlated significantly with C-Hpa expression. In addition, patients with esophageal cancers that exhibited high C-Hpa expression had a poor prognosis, suggesting that $\mathrm{C}-\mathrm{Hpa}$ is involved in tumor invasion and progression of malignant cells. Endothelial cells of vascular sprout in and at the periphery of tumors showed intense Hpa expres- 

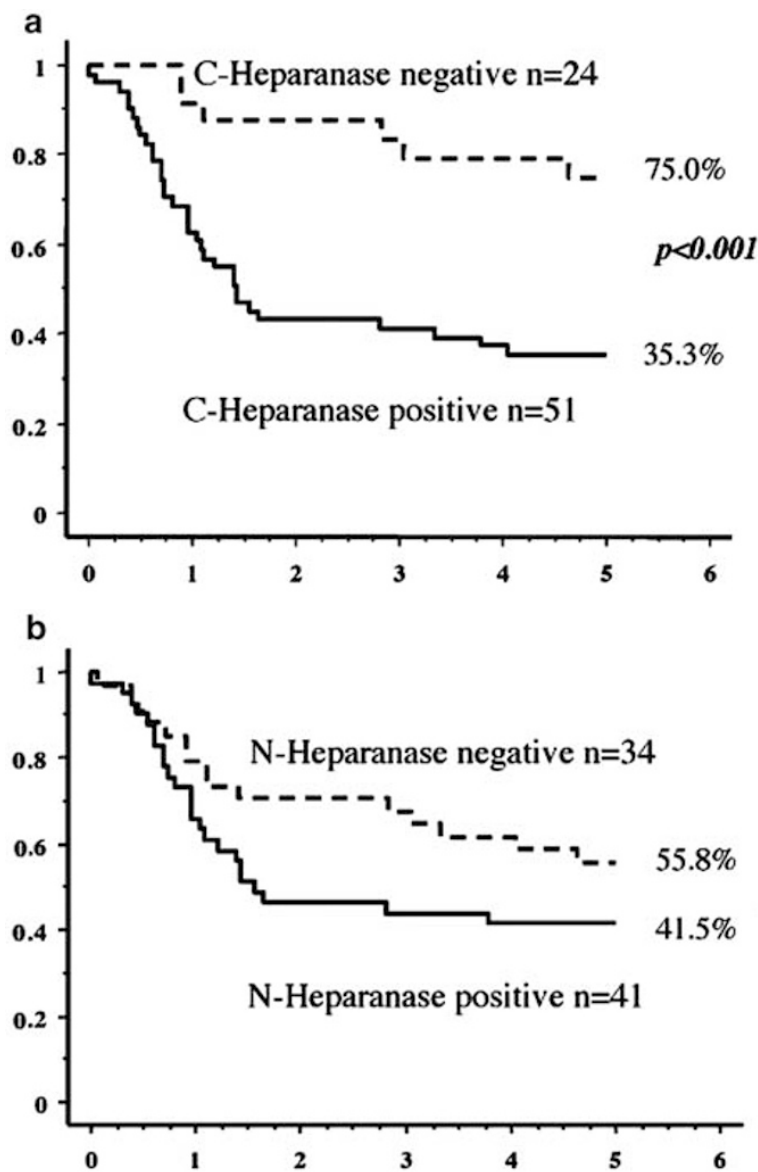

Figure 5 Kaplan-Meier survival curves of patients with esophageal carcinoma that expressed or lacked heparanase $(\mathbf{a}, \mathbf{b})$. (a) Cytoplasmic heparanase-positive patients showed significantly poor survival compared with those with negative expression. (b) Survival of patients with positive nuclear heparanase staining was not different compared with negative nuclear staining cases.

sion. Hpa facilitates angiogenesis by releasing sequestered angiogenetic factors such as VEGF, bFGF from HSPG chains. ${ }^{39,41}$ Microvessel density of tumor tissues correlates with Hpa expression. ${ }^{42-44}$ Our results showed that Hpa expression in metastatic lymph nodes was equal or less in comparison with primary lesions. Similarly, in other studies, findings of high $\mathrm{Hpa}$ expression in primary pancreatic cancers and relatively lower expression in lymph nodes and liver metastasis suggested that Hpa enzymatic activity might be involved in the detachment and escape of tumor cells from the primary site. ${ }^{25}$ However, Friedmann et $a l^{22}$ reported a high Hpa expression in metastatic lesions of colon cancers in lung, liver and lymph nodes. In addition to the structural proteins cleaved by matrix metalloproteinases in the basement membrane and ECM, ${ }^{45}$ Hpa activity may be attributed to the increased requirement for ECM-degrading enzymes at the primary tumor site to allow cancer cells to metastasize. ${ }^{25}$ Once tumor cells metastasize to the regional lymph nodes, liver and other distant organs, there
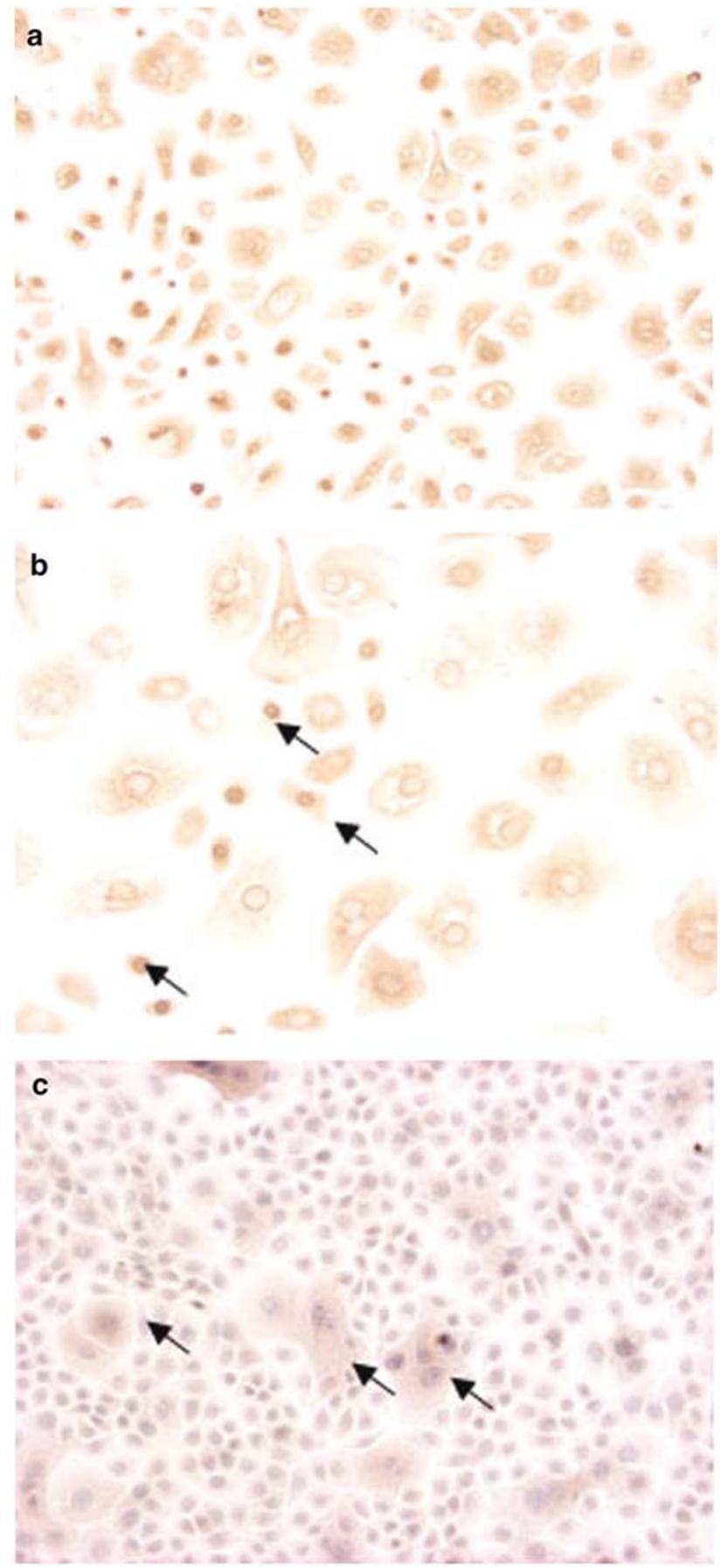

Figure 6 Immunohistochemical analysis of normal esophageal epithelium designed as KOB cell. During differentiation, KOB cells were altered into larger size and flat form. Differentiated large and flat KOB cells showed involucrin expression (c). Differentiated KOB cells have no heparanase protein in nucleus but fairly in cytoplasm. On the other hand, nondifferentiated KOB cells have strong heparanase expression in nucleus $(\mathbf{a}, \mathbf{b})$. Original magnifications: $\times 200(\mathbf{a}, \mathbf{c}), \times 400(\mathbf{b})$.

might be no need for tumor cells to degrade ECM. Several reports have so far demonstrated increased Hpa expression and its relationship with tumor invasion and metastasis in human cancers. ${ }^{21-26,46}$ 

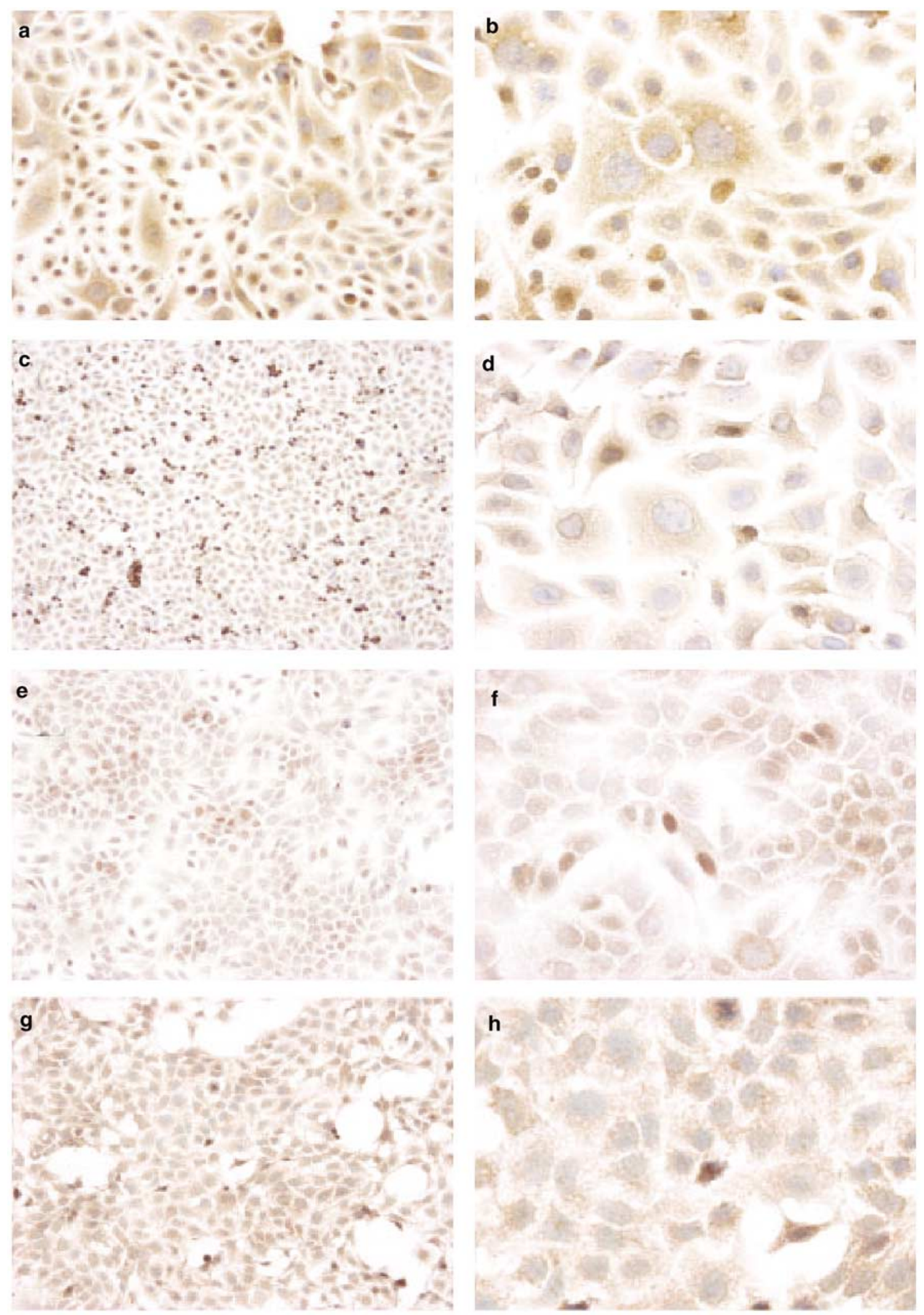

Figure 7 Heparanase expression in cultured esophageal cancer cell lines. Four of esophageal cancer lines (TE1, TE6, TE8 and T.Tn) showed heparanase protein expression. Esophageal squamous cancer cell lines showing similar heparanase staining pattern as like surgical specimens. TE1 and TE6 are well-differentiated squamous cancer cells (a-d). TE-8 (e,f) and T.Tn (g, h) cells are moderately and poorly differentiated squamous cancer cells, respectively. N-Hpa expressed in many TE1 and TE6 cells, while a small number of TE8 and T.Tn cells showed fairly N-Hpa protein expression. Original magnifications: $\times 100(\mathbf{a}, \mathbf{c}, \mathbf{e}$ and $\mathbf{g}), \times 200(\mathbf{b}, \mathbf{d}, \mathbf{f}$ and $\mathbf{h})$. 
However, conflicting results of Hpa expression in ESCC were also reported. Inoue et $a{ }^{47}$ reported that Hpa mRNA expression was decreased in 21 of 38 ESCC and that there were no differences in clinicopathological factors, including prognosis, between high and low expression cases. Ikeguchi et $a l^{48}$ also found that tumor Hpa expression

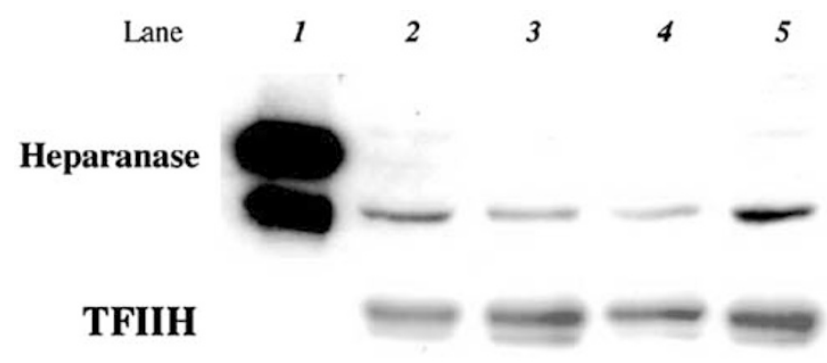

Figure 8 (a) Expression of heparanase in nuclear extract of ESCC cell lines. Lane 1 is recombinant heparanase, 2, TE-1, 3, TE-6, 4, $T E-8$ and 5, T.Tn. All cell lines have heparanase protein in nuclear extract. (b) TFIIH was used as a control of nuclear protein. decreased according to tumor progress and correlated with the occurrence of apoptotic cancer cells. Although we can not explain exactly these discre-

Table 2 Relationship between N-Hpa and CK10 expression in cancer differentiation

\begin{tabular}{lccc}
\hline & N-Hpa positive & N-Hpa negative & Fisher's odds \\
\hline CK10 positive & 32 & 16 & $P=0.0078$ \\
CK10 negative & 9 & 18 & \\
Well & 26 & 11 & \\
Mod & 14 & 17 & $P=0.0277$ \\
Poor & 1 & 4 & \\
Unknown & 0 & 2 & \\
& & & \\
& CK10 positive & CK10 negative & Fisher's odds \\
Well & & & \\
Mod & 31 & 6 & \\
Poor & 17 & 14 & \\
Unknown & 0 & 5 & \\
& 0 & 2 & \\
\hline
\end{tabular}
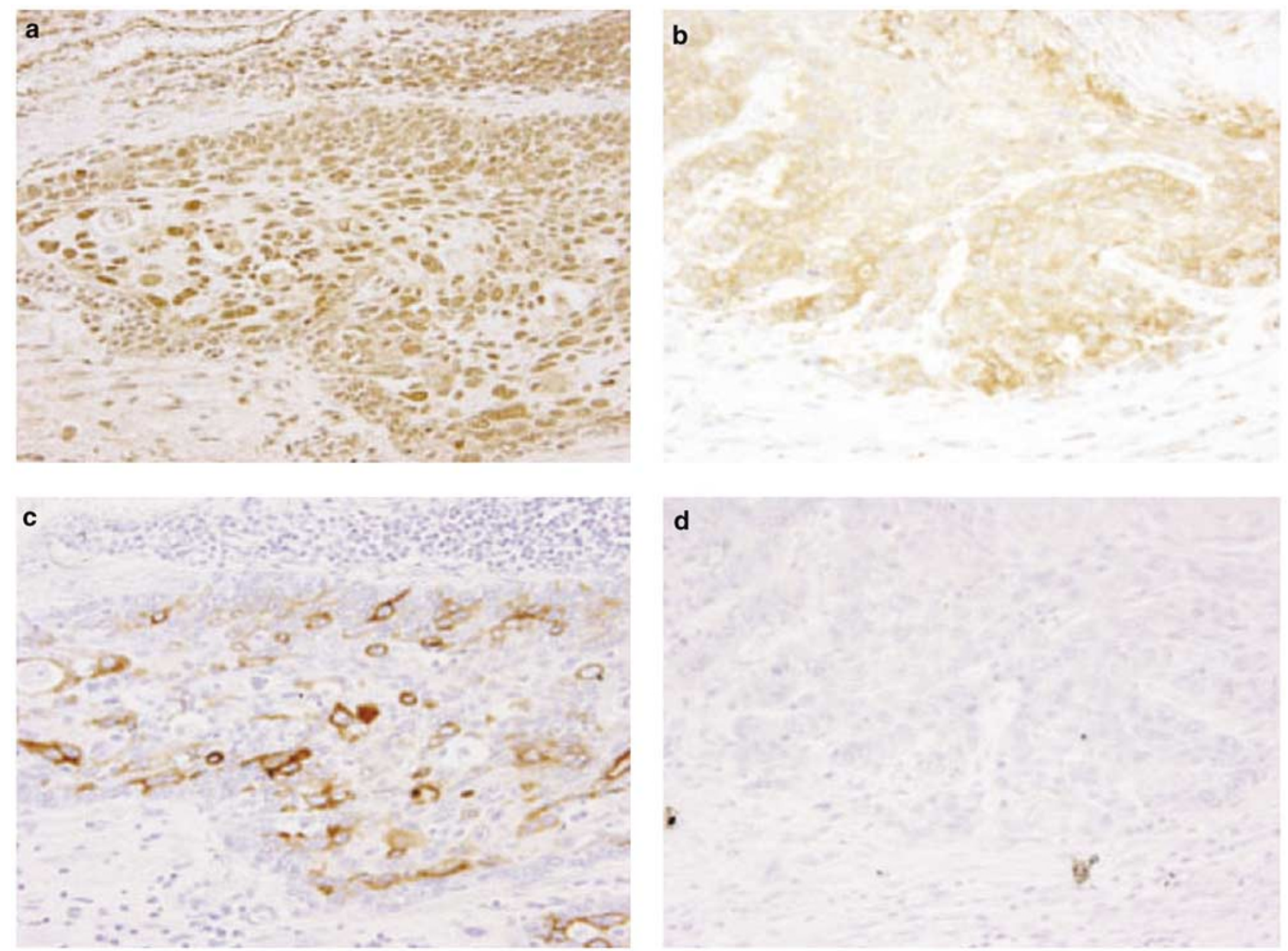

Figure 9 Relationship between heparanase and CK10 expression (a-d). Positive (a). and negative (b) N-Hpa expression. Positive (c) and negative (d) CK10 expression. (a,c) Well-differentiated squamous cell carcinoma with positive staining for heparanase and CK10. (c,d) moderately differentiated squamous cell carcinoma negative for heparanase and CK10. Original magnifications: $\times 200$. 
pancies, one factor could be the different methods used. The two studies, which showed decreased Hpa expression in tumor in progression, examined mRNA expression of $\mathrm{Hpa}$ and compared with clinicopathological factors. However, Hpa mRNA is unstable and is destroyed soon after translation to protein (Dr Motowo Nakajima, Novartis Japan, personal communication). Moreover, platelet is known not to express mRNA but to be rich in heparanase protein. Current work and another study, ${ }^{26}$ both of them used immunohistochemistry as a method, demonstrated similar results, that is, increased Hpa expression in tumor progress. Another possibility could be activation of inhibitory mechanism against Hpa as suggested by Ihrcke et $a l,{ }^{49}$ once invasion by tumor cells was completed and Hpa was not needed anymore.

Hpa protein includes a $50-\mathrm{kDa}$ active and $65-\mathrm{kDa}$ proforms. Previous studies focused on the soluble Hpa protein, which is released outside the cell to degrade the ECM and basement membranes. ${ }^{50,51}$ Therefore, the results of these immunohistochemical studies reflected the cytoplasmic or membranous localization of Hpa. ${ }^{22,52,53}$ However, Nicolson et $a{ }^{54}$ mentioned that Hpa was also expressed in the nuclei of melanoma and breast cancer cells apart from the cell surface and cytoplasm. Our results showed nuclear expression of Hpa in the parabasal layer of the squamous epithelium. We also detected for the first time a strong Hpa expression in nuclei of esophageal cancer cells by immunohistochemical analysis and Western blot.

With regards to clinicopathological elements, NHpa expression in ESCCs patients correlated with the grade of differentiation, depth of invasion and TNM stage but not lymph node metastasis, lymph vessel invasion and survival. In this study, all T4 tumors have N-Hpa expression and this finding reflects to the correlation between $\mathrm{N}-\mathrm{Hpa}$ expression and depth of invasion/TNM stage. N-Hpa might not be involved in tumor invasion and metastasis. Therefore, we analyzed indirectly the function of $\mathrm{N}-\mathrm{Hpa}$ and the results showed that this fraction seems to play a role other than invasion and metastasis. HSPGs, substrates of Hpa, are localized not only in the cell surface and ECM but also in the nuclei of fibroblasts and neurons. The mechanisms of nuclear translocation of Hpa are not clear at present. However, nuclear HSPGs were reported to be involved in the regulation of cell division and survival in the nervous systems. ${ }^{55,56}$ We assume that Hpa translocated from the cytoplasm to the nucleus and cleaved HSPGs in the nucleus, which in turn modulated cell growth through regulation of cell cycle as reported previously for glycosaminoglycans in the nucleus. ${ }^{55}$

Hpa was expressed in the nuclei of normal epithelial cells at the growth layer and at tumor edge. In addition, Hpa protein in KOB cells disappears after differentiation. These results suggest that Hpa might be involved in cell proliferation or differentiation. To test this, we examined the expressions of PCNA and CK10, which reflect the proliferative state and differentiation of the cell, respectively. We also compared Hpa expression with PCNA and CK10 expression. With regard to proliferation, both PCNA and Hpa were expressed at the tumor edge, and their staining patterns were similar. However, our results suggested that $\mathrm{N}-\mathrm{Hpa}$ was not involved in cell proliferation since no significant relationship was found between $\mathrm{Hpa}$ and PCNA expression in cancer cells, although double-staining by using anti-Hpa and anti-PCNA antibodies showed coexpression of PCNA and Hpa in some cells. In fact, PCNA was expressed in the proliferative basal layer of epithelial cells while Hpa was not. Para-basal layer cells are differentiated to keratinocytes from basal layer cells. We previously reported that Hpa in adenovirus-transfected cancer cell lines grew in a manner similar to that of deletion vector transfected cancer cell lines. ${ }^{57}$

On the other hand, CK10 is a differentiation marker of squamous epithelium and is not expressed in normal esophageal epithelium. ${ }^{30,31}$ In ESCC, CK10 was expressed in these tumors and the expression level correlated with the degree of keratinization, a feature of tumor differentiation. In our study, a significant correlation was detected between N-Hpa and CK10. Moreover, each of N-Hpa and CK10 expression also significantly correlated with tumor differentiation. Immunohistochemical study (Figure 6) showed that N-Hpa was detected stronger in well-differentiated squamous cancer cell lines than in poorly differentiated cell lines. Shirakawa et $a l^{32}$ reported that the degree of differentiation of esophageal dysplasia and ESCC correlated with p21 ${ }^{\mathrm{WAF} 1 / \mathrm{CIP} 1}$ and CK10 expression. Taken together, our data suggest that N-Hpa is involved in tumor cell differentiation.

In conclusion, we have demonstrated in the present study that Hpa is expressed in both the cytoplasm and nuclei of carcinoma cells. C-Hpa expression correlated with the invasive properties of esophageal carcinoma. To our knowledge, this is the first report showing that $\mathrm{N}-\mathrm{Hpa}$ expression in esophageal cancer cells correlates with differentiation and coexpressed with CK10. Further studies are warranted to clarify the function of $\mathrm{N}-\mathrm{Hpa}$ and mechanism of its nuclear translocation.

\section{References}

1 Boring CC, Squires TS, Tong T, et al. Cancer statistics, 1994. CA Cancer J Clin 1994;44:7-26.

2 Daly JM, Fry WA, Little AG, et al. Esophageal cancer: results of an American College of Surgeons Patient Care Evaluation Study. J Am Coll Surg 2000;190: 562-572. discussion 572-563.

3 Sagar PM, Gauperaa T, Sue-Ling H, et al. An audit of the treatment of cancer of the oesophagus. Gut 1994; 35:941-945. 
4 Nakajima M, Irimura T, Nicolson GL. Heparanases and tumor metastasis. J Cell Biochem 1988;36:157-167.

5 Bernfield M, Gotte M, Park PW, et al. Functions of cell surface heparan sulfate proteoglycans. Annu Rev Biochem 1999;68:729-777.

6 Ruoslahti E, Yamaguchi Y. Proteoglycans as modulators of growth factor activities. Cell 1991;64:867-869.

7 Hulett MD, Freeman C, Hamdorf BJ, et al. Cloning of mammalian heparanase, an important enzyme in tumor invasion and metastasis. Nat Med 1999;5: 803-809.

8 Vlodavsky I, Friedmann Y, Elkin M, et al. Mammalian heparanase: gene cloning, expression and function in tumor progression and metastasis. Nat Med 1999;5: 793-802.

9 Vlodavsky I, Korner G, Ishai-Michaeli R, et al. Extracellular matrix-resident growth factors and enzymes: possible involvement in tumor metastasis and angiogenesis. Cancer Metast Rev 1990;9:203-226.

10 Bame KJ, Robson K. Heparanases produce distinct populations of heparan sulfate glycosaminoglycans in Chinese hamster ovary cells. J Biol Chem 1997;272: 2245-2251.

11 Bashkin P, Razin E, Eldor A, et al. Degranulating mast cells secrete an endoglycosidase that degrades heparan sulfate in subendothelial extracellular matrix. Blood 1990;75:2204-2212.

12 Goshen R, Hochberg AA, Korner G, et al. Purification and characterization of placental heparanase and its expression by cultured cytotrophoblasts. Mol Hum Reprod 1996;2:679-684.

13 Graham LD, Underwood PA. Comparison of the heparanase enzymes from mouse melanoma cells, mouse macrophages, and human platelets. Biochem Mol Biol Int 1996;39:563-571.

14 Lider O, Baharav E, Mekori YA, et al. Suppression of experimental autoimmune diseases and prolongation of allograft survival by treatment of animals with low doses of heparins. J Clin Invest 1989;83:752-756.

15 Matzner Y, Bar-Ner M, Yahalom J, et al. Degradation of heparan sulfate in the subendothelial extracellular matrix by a readily released heparanase from human neutrophils. Possible role in invasion through basement membranes. J Clin Invest 1985;76:1306-1313.

16 Parish CR, Coombe DR, Jakobsen KB, et al. Evidence that sulphated polysaccharides inhibit tumour metastasis by blocking tumour-cell-derived heparanases. Int J Cancer 1987;40:511-518.

17 Pikas DS, Li JP, Vlodavsky I, et al. Substrate specificity of heparanases from human hepatoma and platelets. J Biol Chem 1998;273:18770-18777.

18 Pillarisetti S, Paka L, Sasaki A, et al. Endothelial cell heparanase modulation of lipoprotein lipase activity. Evidence that heparan sulfate oligosaccharide is an extracellular chaperone. J Biol Chem 1997;272: 15753-15759.

19 Vlodavsky I, Eldor A, Haimovitz-Friedman A, et al. Expression of heparanase by platelets and circulating cells of the immune system: possible involvement in diapedesis and extravasation. Invasion Metast 1992; 12:112-127.

20 Vlodavsky I, Mohsen M, Lider O, et al. Inhibition of tumor metastasis by heparanase inhibiting species of heparin. Invasion Metast 1994;14:290-302.

21 Endo K, Maejara U, Baba H, et al. Heparanase gene expression and metastatic potential in human gastric cancer. Anticancer Res 2001;21:3365-3369.
22 Friedmann Y, Vlodavsky I, Aingorn H, et al. Expression of heparanase in normal, dysplastic, and neoplastic human colonic mucosa and stroma. Evidence for its role in colonic tumorigenesis. Am J Pathol 2000;157: 1167-1175.

23 Ginath S, Menczer J, Friedmann Y, et al. Expression of heparanase, Mdm2, and erbB2 in ovarian cancer. Int J Oncol 2001;18:1133-1144.

24 Gohji K, Okamoto M, Kitazawa S, et al. Heparanase protein and gene expression in bladder cancer. J Urol 2001b;166:1286-1290.

25 Koliopanos A, Friess H, Kleeff J, et al. Heparanase expression in primary and metastatic pancreatic cancer. Cancer Res 2001;61:4655-4659.

26 Mikami S, Ohashi K, Usui Y, et al. Loss of syndecan-1 and increased expression of heparanase in invasive esophageal carcinomas. Jpn J Cancer Res 2001;92: 1062-1073.

27 Freeman C, Parish CR. A rapid quantitative assay for the detection of mammalian heparanase activity. Biochem J 1997;325:229-237.

28 Nakajima M, Irimura T, Di Ferrante N, et al. Metastatic melanoma cell heparanase. Characterization of heparan sulfate degradation fragments produced by B16 melanoma endoglucuronidase. J Biol Chem 1984; 259:2283-2290.

$29 \mathrm{Hu}$ YC, Lam KY, Law S, et al. Profiling of differentially expressed cancer-related genes in esophageal squamous cell carcinoma (ESCC) using human cancer cDNA arrays: overexpression of oncogene MET correlates with tumor differentiation in ESCC. Clin Cancer Res 2001;7:3519-3525.

30 Boisvieux-Ulrich E, Le Pechon-Vallee C, Million K, et al. Differential effects of several retinoid receptorselective ligands on squamous differentiation and apoptosis in airway epithelial cells. Cell Tissue Res 2000;300:67-81.

31 Lam KY, Loke SL, Shen XC, et al. Cytokeratin expression in non-neoplastic oesophageal epithelium and squamous cell carcinoma of the oesophagus. Virchows Arch 1995;426:345-349.

32 Shirakawa Y, Naomoto Y, Kimura M, et al. Topological analysis of p21WAF1/CIP1 expression in esophageal squamous dysplasia. Clin Cancer Res 2000;6:541-550.

33 Jass JR, Sobin LH, Watanabe H. The World Health Organization's histologic classification of gastrointestinal tumors. A commentary on the second edition. Cancer 1990;66:2162-2167.

34 Andl CD, Mizushima T, Nakagawa H, et al. Epidermal growth factor receptor mediates increased cell proliferation, migration, and aggregation in esophageal keratinocytes in vitro and in vivo. J Biol Chem 2003; 278:1824-1830.

35 Takaoka M, Naomoto Y, Ohkawa T, et al. Heparanase expression correlates with invasion and poor prognosis in gastric cancers. Lab Invest 2003;83:613-622.

36 Yamamoto $\mathrm{H}$, Adachi $\mathrm{Y}$, Itoh $\mathrm{F}$, et al. Association of matrilysin expression with recurrence and poor prognosis in human esophageal squamous cell carcinoma. Cancer Res 1999;59:3313-3316.

37 Bar-Ner M, Mayer M, Schirrmacher V, et al. Involvement of both heparanase and plasminogen activator in lymphoma cell-mediated degradation of heparan sulfate in the subendothelial extracellular matrix. J Cell Physiol 1986;128:299-306.

38 Nakajima M, Irimura T, Di Ferrante D, et al. Heparan sulfate degradation: relation to tumor invasive and 
metastatic properties of mouse B16 melanoma sublines. Science 1983;220:611-613.

39 Vlodavsky I, Elkin M, Pappo O, et al. Mammalian heparanase as mediator of tumor metastasis and angiogenesis. Isr Med Assoc J 2000;(Suppl 2):37-45.

40 Marchetti D, Li J, Shen R. Astrocytes contribute to the brain-metastatic specificity of melanoma cells by producing heparanase. Cancer Res 2000;60:4767-4770.

41 Elkin M, Ilan N, Ishai-Michaeli R, et al. Heparanase as mediator of angiogenesis: mode of action. FASEB J 2001;15:1661-1663.

42 El-Assal ON, Yamanoi A, Ono T, et al. The clinicopathological significance of heparanase and basic fibroblast growth factor expressions in hepatocellular carcinoma. Clin Cancer Res 2001;7:1299-1305.

43 Kelly T, Miao HQ, Yang Y, et al. High heparanase activity in multiple myeloma is associated with elevated microvessel density. Cancer Res 2003;63: 8749-8756.

44 Gohji K, Hirano H, Okamoto M, et al. Expression of three extracellular matrix degradative enzymes in bladder cancer. Int J Cancer 2001a;95:295-301.

45 Chambers AF, Matrisian LM. Changing views of the role of matrix metalloproteinases in metastasis. J Natl Cancer Inst 1997;89:1260-1270.

46 Rohloff J, Zinke J, Schoppmeyer K, et al. Heparanase expression is a prognostic indicator for postoperative survival in pancreatic adenocarcinoma. Br J Cancer 2002;86:1270-1275.

47 Inoue H, Mimori K, Utsunomiya T, et al. Heparanase expression in clinical digestive malignancies. Oncol Rep 2001;8:539-542.

48 Ikeguchi M, Fukuda K, Yamaguchi K, et al. Quantitative analysis of heparanase gene expression in esophageal squamous cell carcinoma. Ann Surg Oncol 2003;10:297-304.
49 Ihrcke NS, Parker W, Reisssner KJ, et al. Regulation of platelet heparanase during inflammation: role of $\mathrm{pH}$ and proteinases. J Cell Physiol 1998;175:255-267.

50 Toyoshima M, Nakajima M. Human heparanase. Purification, characterization, cloning, and expression. J Biol Chem 1999;274:24153-24160.

51 Okada Y, Yamada S, Toyoshima M, et al. Structural recognition by recombinant human heparanase that plays critical roles in tumor metastasis:hierarchical sulfate groups with differential effects and the essential target disulfated trisaccharide sequence. J Biol Chem 2002;277:42488-42495.

52 Goldshmidt O, Zcharia E, Abramovitch R, et al. Cell surface expression and secretion of heparanase markedly promote tumor angiogenesis and metastasis. Proc Natl Acad Sci USA 2002;99:10031-10036.

53 Jin L, Nakajima M, Nicolson GL. Immunochemical localization of heparanase in mouse and human melanomas. Int J Cancer 1990;45:1088-1095.

54 Nicolson GL, Nakajima M, Herrmann JL, et al. Malignant melanoma metastasis to brain: role of degradative enzymes and responses to paracrine growth factors. J Neurooncol 1994;18:139-149.

55 Liang Y, Haring M, Roughley PJ, et al. Glypican and biglycan in the nuclei of neurons and glioma cells: presence of functional nuclear localization signals and dynamic changes in glypican during the cell cycle. J Cell Biol 1997;139:851-864.

56 Richardson TP, Trinkaus-Randall V, Nugent MA. Regulation of heparan sulfate proteoglycan nuclear localization by fibronectin. J Cell Sci 2001;114(Part 9): 1613-1623.

57 Uno F, Fujiwara T, Takata Y, et al. Antisense-mediated suppression of human heparanase gene expression inhibits pleural dissemination of human cancer cells. Cancer Res 2001;61:7855-7860. 